\title{
PENGARUH KADAR FERRITIN SERUM TRANSFUSI DARAH BERULANG TERHADAP GANGGUAN PERTUMBUHAN PADA ANAK THALASSEMIA $\beta$ MAYOR
}

\author{
Cheryl Nini \\ Fakultas Kedokteran Universitas Islam Al-Azhar \\ J1. Unizar No.20 Turida Mataram
}

\begin{abstract}
ABSTRAK
Latar belakang. Kadar ferritin serum transfusi darah berulang merupakan petanda iron overload yang dapat menyebabkan hemokromatosis dan gangguan pertumbuhan. Sebagian besar pasien thalassemia ditemukan mengalami gangguan pertumbuhan yang signifikan.

Tujuan. Mengetahui pengaruh kadar ferritin serum transfusi darah berulang terhadap gangguan pertumbuhan pada anak thalassemia mayor

Metode. Penelitian berupa analitik observasional potong lintang, dilakukan pada bulan Agustus-Oktober 2017 pada pasien thalassemia $\beta$-mayor. Penelitian uji diagnostik pada pasien thalassemia mayor usia 3 tahun - prepubertas dilakukan pada semua subyek. Dilakukan analisis receiver operator curve ( $\mathrm{ROC}$ ).

Hasil. Subyek thalassemia mayor yang transfusi berulang telah menjalani terapi kelasi besi deferioksamin namun kualitasnya tidak memadai, semua subyek mempunyai kecepatan tumbuh $<5$ $\mathrm{cm} /$ tahun. Kadar ferritin serum di atas $3000 \mu \mathrm{g} / \mathrm{ml}$, dan semua subyek mempunyai perawakan pendek. Pada evaluasi radiologi manus sinistra anak memiliki usia tulang terlambat. Proprsi usia tulang terlambat pada kelompok subyek dengan gangguan pertumbuhan lebih besar meski perbedaannya secara statistic tidak bermakna.
\end{abstract}

Kesimpulan. Kadar ferritin pada transfusi darah berulang tidak cukup akurat untuk memprediksi gangguan pertumbuhan pada anak thalassemia mayor.,

Kata Kunci: Thalassemia, kadar ferritin serum, transfusi berulang, gangguan pertumbuhan.

\section{PENDAHULUAN}

Thalassemia adalah kelainan bawaan sintesis, dan salah satu penyakit monogenetic paling banyak di dunia. Pada tahun 1994 World Health Organization (WHO) menyatakan 4,5\% dari total penduduk dunia adalah pembawa sifat thalassemia dan meningkat menjadi $7 \%$ pada tahun $2001 .^{1}$ Diperkirakan 300-400 ribu bayi thalassemia mayor lahir pertahun di seluruh dunia. Di Indonesia angka pembawa sifat thalassemia- $\beta$, thalassemia- $\alpha$ dan $\mathrm{HbE}$ berturut-turut 3$10 \%$, 1,2-11\%, dan 1,5-36\%. ${ }^{2}$ Pasien thalassemia mayor secara klinis ditandai dengan anemia berat, dan memerlukan perhatian medis di tahun pertama kehidupan. Transfusi darah berulang, pemberian terapi kelasi besi subkutan meningkatkan prognosis jangka panjang, namun akan timbul masalah yang berhubungan dengan hemosiderosis sekunder yang berimbas pada kerusakan beberapa organ, terutama jantung, hati, dan kelenjar endokrin. ${ }^{3-6}$

Penyebab gangguan pertumbuhan pada thalassemia mayor adalah multifaktorial, pathogenesis pasti belum dapat dijelaskan. Di antara factor yang berpengaruh adalah pemberian transfuse darah suboptimal, kelebihan besi, toksisitas deferioksamin (DFO), pubertas terlambat, dan gangguan aksis hormone 
pertumbuhan-insulin like growth-factor (IGF-I). ${ }^{5,7-8}$ kadar ferritin serum dilaporkan memiliki hubungan langsung dengan tingkat gangguan pertumbuhan atau penurunan kecepatan tumbuh pada pasien thalassemia. ${ }^{9}$

Berbagai penelitian melaporkan adanya gangguan pertumbuhan pada anak dengan thalassemia. Penelitian potong lintang pada anak thalassemia- $\beta$ mayor di Cina melaporkan $75 \%$ perempuan dan $62 \%$ laki-laki berumur lebih dari 12 tahun mengalami pertumbuhan terhambat. ${ }^{10}$ penelitian yang dilakukan oleh Pemde dkk $^{11}$ di India tahun 2011 melaporkan $33,11 \%$ pasien thalassemia mayor yang tergantung dengan transfuse mengalami perawakan pendek yang berhubungan dengan kelebihan besi. Penelitian Made dan Ketut $^{12}$ tahun 2011 menunjukkan pada 15 subyek thalassemia mayor semuanya memiliki kecepatan tumbuh $<5$ $\mathrm{cm} /$ tahun dan 4 orang (26\%) tergolong perawakan pendek.

Pertumbuhan ialah bertambahnya ukuran dan jumlah sel serta jaringan intraselular, berarti ukuran fisik dan struktur tubuh yang bertambah dalam arti sebagian atau keseluruhan, bersifat kuantitatif sehingga dapat diukur dengan menggunakan satuan panjang atau satuan berat. $^{13}$ faktor yang mempengaruhi pertumbuhan adalah genetic, etnis, berat badan dan prematuritas, hormone, gizi dan lingkungan. ${ }^{14,15}$
Beberapa penelitian telah mendapatkan adanya retardasi pertumbuhan pada pasien thalassemia $\beta$ mayor. Gomber $\mathrm{dkk}^{16}$ mendapatkan tinggi badan $<\mathrm{P}_{3}$ pada $34,5 \%$ anak dengan thalassemia $\beta$ mayor dan terutama terdapat pada kelompok usia $\geq 10$ tahun, sedangkan Baker $\mathrm{dkk}^{17}$ mendapatkan tinggi badan $<\mathrm{P}_{5}$ pada $61 \%$ anak dengan thalassemia $\beta$ mayor. Kadar hemoglobin $(\mathrm{Hb})$ pre-transfusi dan ferritin serum mempengaruhi pertumbuhan anak dengan thalassemia $\beta$ mayor. Pemde dkk $^{11}$ mendapatkan adanya korelasi dengan arah negative yang bermakna secara statistic antara kadar ferritin serum dengan Z-score tinggi badan menurut umur. Hattab ${ }^{18}$ mendapatkan retardasi pertumbuhan seluruh pasien pada semua usia, 75,9\% pasien dengan berat badan dan tinggi badan $<\mathrm{P}_{10}$ serta $38,7 \%$ IMT $<\mathrm{P}_{10}$. Retardasi pertumbuhan yang lebih berat terjadi pada pasien usia $>10$ tahun. Tidak terdapat perbedaan jenis kelamin pada penelitian ini.

Pencegahan dan tatalaksana abnormalitas pertumbuhan pada pasien thalassemia mayor antara lain,

- Transfusi darah yang tepat untuk mempertahankan kadar $\mathrm{Hb}>9 \mathrm{~g} / \mathrm{dl}$.

- Kelasi yang tepat untuk mencapai ferritin serum $<1000 \mathrm{mg} / \mathrm{ml}$.

- Penggunaan kelasi besi yang baru dengan toksisitas yang lebih rendah pada tulang dan kepatuhan pasien yang lebih baik. 
- Koreksi bila tersangka kekurangan gizi (kalori, protein, vitamin $\mathrm{D}$, folat, , vitamin A, seng dan karnitin).

- Koreksi hipersplenisme

- Diagnosis dan tatalaksana yang tepat ketrlambatan pertumbuhan (pengobatan growth hormone).

- Tatalaksana sesuai dengan waktu yang tepat untuk keterlambatan pibertas pada anaka lelaki dan perempuan dan induksi pubertas untuk mencapai pertumbuhan pubertas dan tulang yang normal.

- Diagnosis yang tepat dan tatalaksana dini hipotiroidisme dan hemostasis glukosa yang abnormal (toleransi glukosa terganggu dan diabetes mellitus) ${ }^{19}$

\section{METODE}

Pada jurnal Sari Pediatri, Vol. 13, No. 4, Desember 2011 laporan serial kasus pada anak dengan diagnosis thalassemia mayor yang dirawat inap di Bagian Ilmu Kesehatan Anak FK UNUD/RSUP Sanglah Denpasar dari bulan Desember 2010-Februari 2011. Kriteria inklusi adalah pasien thalassemia mayor yang mendapat transfusi berulang dan memiliki catatan medis lengkap. Sedangkan pasien dieksklusi apabila menderita penyakit lain seperti diabetes mellitus, hipertensi atau kelainan jantung pada pemeriksaan ekokardiografi, kegagalan adrenal dan lain-lain. Semua pasien mendapat transfusi secara teratur.

Pada jurnal Sari Pediatri, Vol. 19, No. 6, April 2018 rancangan penelitian adalah observasional potong lintang. Pengambilan sampel dilakukan di Thalassemia Centre RSUD Arifin Achmad Pekanbaru mulai bulan Agustus sampai dengan Oktober 2017. Kriteria inklusi adalah semua pasien anak terdiagnosis thalaseemia $\beta$ berusia 1-18 tahun, telah menjalani transfusi darah teratur selama minimal 1 tahun dan atau kadar ferritin serum > $1.000 \mathrm{mg} / \mathrm{mL}$. kriteria eksklusi adalah pasien dengan kelainan skeletal, penyakit jantung bawaan, gagal jantung kronik dan tuberculosis serta pasien yang menjalani pengobatan hormonal.

Pada jurnal Sari Pediatri, Vol. 18, No. 2, Agustus 2016 penelitian uji diagnostic yang dilakukan di RSUP Dr. Mohammad Hoesin Palembang (RSMH) pada bulan April - Desember 2015. Sampel diambil secara consecutive sampling. Kriteria inklusi penelitian adalah semua pasien thalassemia mayor usia 3 tahun- usia prepubertas yang bersedia ikut penelitian. Kriteria eksklusi adalah adanya penyakit lain, seperti diabetes mellitus, hipertensi atau kelainan jantung pada pemeriksaan ekokardiografi, pasien yang sedang dalam keadaan infeksi atau inflamasi akut dan pasien dengan gizi buruk. Laju pertumbuhan 
rata-rata subyek penelitian adalah $<2 \mathrm{~cm} /$ 6 bulan, tertinggi $4,8 \mathrm{~cm} / 6$ bulan, dan terendah $0 \mathrm{~cm} / 6$ bulan. Limapuluh subyek yang dapat dilakukan pemeriksaan usia tulang karena sulit penjadwalan. Ditemukan $30(60 \%)$ subyek dari yang diperiksa mengalami usia tulang terlambat. Kadar ferritin serum subyek dengan laju pertumbuhan terlambat adalah $3075 \mu \mathrm{g} / \mathrm{L}$, lebih tinggi dibandingkan dengan subyek dengan laju pertumbuhan tidak terlambat meski secara statistik perbedaanya tidak bermakna.

\section{HASIL}

Untuk mengetahui akurasi kadar ferritin serum dalam memprediksi laju pertumbuhan pada pasien thalassemia mayor, dilakukan analisis dengan metode receiver operator curve (ROC). Nilai area under the curve (AUC) yang diperoleh dari metode ROC untuk kadar ferritin serum adalah 66,2\% (IK95\%: 52,1\%$80,4 \%), \quad \mathrm{p}=0,028$. Berdasarkan hasil penelitian dicari titik potong (cut off point) kadar ferritin serum yang dapat menyebabkan iron overload. Didapatkan nilai cut off point $\geq 2599 \mu \mathrm{g} / \mathrm{L}$. nilai diagnosik untuk kadar ferritin serum memiliki sensitivitas 58,9\%, spesifisitas $60 \%$, nilai duga positif $83,3 \%$, nilai duga negative $30 \%$, rasio kemungkinan positif 1,43 rasio kemungkinan negatif 0,7 dan akurasi 59,1\%. Berdasarkan data 50 subyek yang dapat dilakukan pemeriksaan usia tulang radiologis, dicari perbedaan proporsi usia tulang terlambat pada subyek dengan pertumbuhan terlambat dibandingkan dengan pertumbuhan tidak terlambat. Proporsi subyek dengan usia tulang terlambat lebih besar pada kelompok dengan gangguan pertumbuhan, yaitu 25 dari 38 anak $(65,8 \%)$ dibandingkan pada subyek tanpa gangguan pertumbuhan, yaitu 5 dari 12 anak (41,7\%), meski secara statistic perbedaan tersebut belum bermakna (uji Fisher exact, $\mathrm{p}=0,14$ )

\section{PEMBAHASAN}

Pertumbuhan terhambat sering terjadi pada pasien thalassemia mayor anak dan remaja, namun pada umumnya tidak segera terdeteksi pada sebagian besar pasien. Sebelum era hipertransfusi dan terapi kelasi besi, hipoksia jaringan dan toksisitas besi merupakan penyebab utama pertumbuhan terhambat. 20,21,22 Faktor kelebihan besi berakibat terhadap gangguan produksi IGF-I (somatomedin) sehingga kadar di dalam darah rendah. Penurunan secara bermakna aktifitas IGFI berdampak terutama pada pertumbuhan kartilago tulang. Gangguan pertumbuhan mulai tampak setelah usia 10 tahun. Pada kelompok umur setelah 10 tahun ditemukan pula pemendekan badan (tinggi duduk).

Kadar ferritin serum merupaka salah satu parameter yang digunakan 
untuk mengukur kelebihan besi pada tubuh. Penelitian yang dilakukan oleh Shalitin $\mathrm{dkk}^{23}$ Gomber dan Dewan ${ }^{16}$ melaporkan bahwa ketika kadar ferritin meningkat lebih dari $3000 \mu \mathrm{g} / \mathrm{L}$ akan terjadi gangguan pertumbuhan. Terdapat banyak factor yang mempengaruhi gangguan pertumbuhan pada thalassemia selain toksisitas besi, antara lain anemia kronik yang menyebabkan hipoksia jaringan, penyakit liver kronis, dan defisiensi nutrisi yang belum diperhitungkan dalam penelitian ini. Pengaruh toksisitas besi terhadap laju pertumbuhan juga dipengaruhi lamanya pajanan terhadap iron overload.

\section{KESIMPULAN}

Kadar ferritin serum tidak cukup akurat untuk menentukan laju pertumbuhan pada pasien thalassemia meski pada pemeriksaan usia tulang mendukung toksisitas besi pada sebagian besar subyek. Kemungkinan hasil demikian terjadi karena banyak factor lain yang berpengaruh seperti anemia kronis, hipoksia, penyakit hati kronis, defisiensi nutrisi, usia dan lama penyakit. Penelitian lebih lanjut hendaknya juga mempertimbangkan adanya factor tersebut untuk memprediksi gangguan pertumbuhan pada anak dengan thalassemia.

Perlu dilakukan penelitian labih lanjut mengenai pemakaian terapi kelasi besi, deferioksamin (DFO) untuk menurunkan kadar besi pada hipertransfusi pasien thalassemia mayor.

\section{DAFTAR PUSTAKA}

Run D, Rachmilewitz E. $\beta$-Thalassemia. N Engl J Med 2005;1135-46

Wahidiyat PA. Komplikasi pada talasemia mayor. Dalam: Subanada IB, Kumara Wati KD, Sidiartha IGL, Lingga Utama IMGD, Supartha M, Setyorini A dkk, penyunting. Pendidikan Kedokteran Berkelanjutan Ilmu Kesehatan Anak X FK UNUD/RSUP Sanglah. Denpasar: Bagian IKA FK UNUD, 2010.h.119-32.

Alatzoglou KS, Dattani MT. Acquired disorders of the hypothalamopituitary axis. Dalam: Brook C, Clayton P, Brown R, penyunting. Brook's Clinical Pediatric Endocrinology. Edisi ke-6. West Sussex UK: Wiley-Backwell Publishing; 2009.h.106-23.

Low LCK. Growth of children with $\beta$ thalassemia major. Indian pediatr 2005;72:159-63.

De Sanctis V, Pinamonti A, Di Palma A, Sprocati M, Atti G, Gamberini MR dkk. Growth and development in thalassemia major patients with severe bone lesions due to desferrioxamine. Eur J Pediatr 1996;155:368-72.

Saxena A. Growth Retardation in thalassemia major patients. Int $\mathbf{J}$ Hum Genet 2003;3:237-46.

Katzos G, Harsoulis F, Papadopoulou M, Athanasiou M, Sava K. Circadian growth hormone secretion in short multitransfused prepubertal children with thalassemia major. Eur J Pediatr 1995;154:445-9.

De Virgiliis S, Congia M, Frau F, Argiolu F, Diana G, Cucca F, dkk. 
Deferoxamine-induced growth retardation in patients with thalassemia major. J Pediatr 1988;113:661-9.

Shalitin S, Carmi D, Weintrob N, Philip M, Miskin H, Kornreich L, dkk. Serum Ferritin level as predictor of impaired growth and puberty in thalassemia major patients. Eur $\mathbf{J}$ Haematol 2005;74:93-100.

Kwan EYW, Lee ACW, Li AMC, Tam SCF, Chan CF, Lau YL, Low LCK. A Cross-sectional study of growth, puberty and endocrine function in patients with thalassemia major in Hongkong. J Paeditr Child Health 1998;34:47-52.

Pemde KH, Chandra J, Gupta D, Singh V, Sharma R, Dutta AK. Physical growth in children with transfusion dependent thalassemia. Pediatr Healt Med Ther. 2011;2:13-9.

Made A, Ketut A. Profil pertumbuhan, hemoglobin pre-transfusi, kadar ferritin, dan usia tulang anak pada thalassemia mayor. Sari Pediatri 2011;13:299-304.

Tanuwidjaya S. Konsep umum tumbuh dan kembang. Dalam:Narendra MB, Sularyo TS, Soetjiningsih, Suyitno H, Ranuh ING, Wiradisuria $\mathrm{S}$, penyunting. Tumbuh kembang anak dan remaja. Edisi ke-1. Jakarta: Sagung Seto;2008.h.1-21.

Department of Education and Early Childhood Development The Royal Children's Hospital Melbourne. Factors affecting growth. 2012 (diakses tanggal 26 April 2017). Diunduh dari http://www.education.vic.gov.au/D ocuments/factoraffgrowth.pdf

Wales JK. Evaluation of growth disorders. Dalam: Brook C, Clayton P, Brown R, penyunting. Brook C, Clayton P, Brown R, penyunting. Brook's clinical pediatric endocrinology. Ediasi ke-
6. Oxford: WileyBlackwell;2009.h.124-54.

Gomber S, Dewan P. Physical growth patterns and dental caries in thalassemia. Indian Pediatr 2006;43:1064-9.

Baker N, Alnakashabandi A, Alsaqy AH, Alrabaty A. Growth pattern and sexual maturation rate in $\mathrm{B}$ thalassemia Mayor patient from thalassemia center Erbil. Iraqy Postgrad Med J 2013;12:40-5.

Hattab FN. Patterns of physical growth and dental development in Jordanian children and adolescent with thalassemia major. J Oral Sci 2013;55:71-7.

Sanctis VD, Skordis N, Soliman AT. Endocrine disease. Dalam:Cappellini MD, Cohen A, Porter J, Taher A, Viprakasit V, penyunting. Guidelines for the management of transfusion dependent thalassemia (tdt). Cyprus: Thalassemia International Federation;2014.h..146-57.

Alatzoglou KS, Dattani MT. Acquired disorders of the hypothalamopituitary axis. Dalam: Brook C, Clayton P, Brown R, penyunting. Brook's Clinical Pediatric Endocrinology. Edisi ke-6. West Sussex UK: Wiley-Backwell Publishing;2009.h.106-23.

Low LCK. Growth of children with $\beta$ thalassemia major. Indian Pediatr 2005;72:159-63.

Borgna-Pignatti C, De Stefano P, Zonta L, Vullo C, De Sanctis V, Melevendi C. growth and sexual maturation inthalassemia major. J Pediatr 1985;106:150-5.

Shalitin S, carmi D, weintrob N, Philip M, Miskin H, Kornreich L, dkk. Serum ferritin level as predictor of impaired growth and puberty in thalassemia major patients. Eur $\mathbf{J}$ Haematol 2005;74:93-100. 